\title{
ANALISIS KESULITAN MATEMATIK SISWA SMP PADA MATERI STATISTIKA
}

\author{
Dara Kartika Dewi ${ }^{1}$, Siti Sarah Khodijah ${ }^{2}$, Luvy Sylviana Zanthy ${ }^{3}$ \\ 1,2,3 IKIP Siliwangi, Jl. Terusan Jenderal Sudirman Cimahi, (022) 6658680 \\ darakartikadewi02@gmail.com
}

\begin{abstract}
This research aim to analyzing student's difficulty in solving statistic problem. This research using qualitative method with qualitative approach. Population in this research is whole student junior Highschool at Kabupaten Bandung Barat with using samples 24 student SMP Cendikia Cililin. Data collection technique using documentation method are student test result based on question instrument in main course of statistic which contain indicator of competence achievement; 1) Determine median value of even number; 2) Determine average from a data; 3) Determine median value of odd number; 4) Analyzing data; 5) Determine modus value from some data. Based on research result and discussion, student difficulties in solving problem are on the indicator determines average values of data with percentage of eror $83 \%$ which is in the high category. The causative factor is the student can not understanding the basic concept of statistic. To communite problem by modeling mathematics, how to manipulated statistic, and collect conclution.
\end{abstract}

Keywords: Analyzing Student's Difficulties, Competency Achievment of Indicator, Statistic

\begin{abstract}
Abstrak
Penelitian ini bertujuan untuk menganalisis kesulitan siswa dalam menyelesaikan soal pada pokok bahasan statistika. Metode penelitian yang digunakan adalah metode kualitatif dengan pendekatan kualitatif. Populasi pada penelitian ini yaitu seluruh siswa SMP di Kabupaten Bandung Barat dengan sampel yang digunakan adalah 24 siswa SMP Bingkai Cendikia Cililin. Teknik pengumpulan data menggunakan metode dokumentasi berupa hasil tes siswa berdasarkan instrumen soal pada pokok bahasan statistika yang memuat indikator pencapaian kompetensi; 1) Menentukan median dari data genap; 2) Menentukan nilai rata-rata dari suatu data; 3) Menentukan nilai median dari data ganjil; 4) Menganalisis data; dan 5) Menentukan nilai modus dari suatu data. Berdasarkan hasil penelitian dan pembahasan, kesulitan siswa dalam menyelesaikan soal statistika berada pada indikator menentukan nilai rata-rata dari suatu data dengan presentase kesalahan $80 \%$ dan pada indikator menganalisis suatu data dengan presentase kesalahan $83 \%$ yang termasuk kategori tinggi. Faktor penyebabnya adalah siswa belum mampu memahami konsep dasar statistika, mengkomunikasikan permasalahan dengan cara memodelkan matematika, melakukan manipulasi statistic, dan menarik kesimpulan.
\end{abstract}

Kata kunci: Analisis Kesulitan Siswa, Indikator Kemampuan Kompetensi, Statistika

\section{PENDAHULUAN}

Pendidikan merupakan hal yang penting dalam kehidupan, dan berperan sebagai wadah bagi manusia untuk mengembangkan kemampuan atau potensi yang ada dalam dirinya. Pendidikan harus mulai diterapkan dari sejak dini. Pendidikan merupakan proses interaksi antara pendidik dan peserta didik yang terdapat pada pendidikan formal, nonformal, maupun informal (Chotimah,S; Ramdhani, F,. A.; Martin Bernard, M.; \& Akbar, 2015). Menurut Chotimah, S., Bernard, M., \& Wulandari, S. M. (Aprilianti \& Zanthy, 2018) "Education has an important role to prepare qualified human resources and to compete in the development of science" yang berarti pendidikan memiliki peranan yang sangat penting dalam mempersiapkan sumber daya manusia (SDM) yang berkualitas dan mampu bersaing dalam dunia sains. Salah satu pendidikan formal yang dipelajari peserta didik yakni matematika.

Matematika berasal dari bahasa Yunani "mathema" yang berarti ilmu atau pengetahuan. Matematika merupakan bidang ilmu yang memiliki peranan sangat penting dalam kehidupan sehari- 
hari. Menurut Cockroft (Farhan \& Zanthy, 2019) "It would be very difficult - perhaps imposible - to live a normal life in very many parts of the world in the twentieth century without making use of mathematics of some kind", yang berarti bahwa dalam menjalani kehidupan di abad ke 20 ini tidak akan mungkin jika tanpa memanfaatkan matematika dalam berbagai bidang.

Matematika merupakan mata pelajaran yang dipelajari mulai dari tingkat sekolah dasar hingga tingkat sekolah menengah. Namun, pada kenyataannya matematika masih dianggap sebagai mata pelajaran yang sulit untuk dipelajari. Hal ini terlihat dari hasil UNBK SMP yang diperoleh pada 2 tahun terakhir, bahwa nilai matematika mengalami penurunan. Hasil UNBK pada tahun 2017 menunjukkan nilai rata-rata 50,34. Sedangkan pada tahun 2018 matematika mengalami penurunan dengan nilai rata-rata 44,05 (Kemendikbud, 2019).

Dalam penelitian ini, peneliti akan menganalisis kesulitan-kesulitan siswa dalam mata pelajaran matematika pada soal materi statistika. Statistika merupakan materi yang dipelajari dalam mata pelajaran matematika, statistika ini dapat bermanfaat dalam kehidupan sehari-hari bahkan digunakan salam segala bidang keilmuan, seperti ekonomi, sosiologi, kesehatan dan bahkan digunakan dalam dunia perkantoran. Menurut Boediono dan Koster (Nisa \& Susanti, 2019) menyatakan bahwa salah satu negara yakni Jepang berhasil menerapkan ilmu statistika khususnya dalam ilmu peluang dalam memasarkan berbagai hasil karya anak bangsanya seperti mobil, motor, dan bahkan barang eletronik lainnya.

Berdasarkan hal tersebut perlu diteliti dan dianalisis lebih lanjut penyebab dari kesulitan siswa dalam mempelajari materi statistika tersebut. Sehingga rumusan dari penelitian ini adalah bagaimana kesulitan siswa dalam menyelesaikan soal materi statistika. Tujuan dari penelitian ini adalah untuk menganalisis kesulitan siswa dalam menyelesaikan soal pada materi statistika.

\section{METODE}

Metode yang digunakan dalam penelitian ini adalah penelitian kualitatif dengan pendekatan deskriptif kualitatif. Penelitian ini menggunakan teknik pengumpulan data dengan metode dokumentasi berupa hasil tes siswa pada pokok bahasan statistika. Penggunaan metode deskriptif kualitatif ini adalah untuk menganalisis sejauh mana kesulitan siswa dalam memecahkan masalah pada soal statistika. Populasi dalam penelitian ini adalah siswa SMP di Kabupaten Bandung Barat, sedangkan sampelnya yaitu 24 siswa kelas IX di SMP Bingkai Cendikia Cililin. Instrumen yang digunakan dalam penelitian ini berupa instrumen test yang terdiri dari 5 butir soal uraian yang masing-masing memuat indikator pencapaian kompetensi siswa, yaitu: 1) Menentukan median dari data genap; 2) Menentukan rata-rata suatu data; 3) Menentukan median dari data ganjil; 4) Menganalisis suatu data; dan 5) Menentukan modus suatu data (As'ari, Tohir, Valentino, Imron, \& Taufiq, 2017).

Adapun analisis tingkat kesulitan siswa dilakukan setelah data terkumpul berdasarkan hasil tes tertulis yang telah dilakukan. Teknik menganalisis data ini yang dilakukan terdiri dari menilai 
jawaban siswa berdasarkan tes yang diberikan, menentukan jenis-jenis kesalahan jawaban oleh siswa dan mengetahui banyaknya jenis kesalahan siswa digunakan suatu rumus presentase berikut:

$P=\frac{n}{N} \times 100$

Keterangan:

$\mathrm{P}=$ Presentase

$\mathrm{n}=$ Banyaknya kesalahan

$\mathrm{N}$ = Banyaknya kemungkinan kesalahan

Adapun kriteria presentase banyaknya kesalahan dari masing - masing jenis kesalahan, dalam penelitian ini merujuk dari Nurkanca dan Sunarta (Faelasofi, 2017).

\section{Tabel 1.}

Kriteria Presentase Banyaknya Kesalahan

\begin{tabular}{ll}
\hline Presentase $(\mathbf{P})$ & Kriteria \\
\hline $90,00 \leq \mathrm{P} \leq 100$ & Sangat tinggi \\
$80,00 \leq \mathrm{P}<90,00$ & Tinggi \\
$65,00 \leq \mathrm{P}<80$ & Sedang \\
$55,00 \leq \mathrm{P}<65$ & Rendah \\
$\mathrm{P}<55,00$ & Sangat Rendah \\
\hline
\end{tabular}

\section{HASIL DAN PEMBAHASAN}

Berikut ini adalah tabel perolehan skor siswa setiap butir soal.

\section{Tabel 2.}

Perolehan Skor Siswa Tiap Butir Soal

\begin{tabular}{|c|c|c|c|c|c|c|}
\hline \multirow{2}{*}{ Jumlah } & \multicolumn{5}{|c|}{ Skor Soal } & \multirow{2}{*}{$\begin{array}{l}\text { Skor } \\
\text { Total }\end{array}$} \\
\hline & 1(10) & 2(20) & 3(10) & $4(30)$ & $5(30)$ & \\
\hline Junlah skor 24 siswa & 63 & 98 & 190 & 122 & 375 & 848 \\
\hline P Benar (\%) & $26 \%$ & $20 \%$ & $79 \%$ & $17 \%$ & $52 \%$ & $35 \%$ \\
\hline P Salah (\%) & $74 \%$ & $80 \%$ & $21 \%$ & $83 \%$ & $48 \%$ & $65 \%$ \\
\hline
\end{tabular}

Berikut akan disajikan persentase rata-rata indikator pencapaian kompetensii siswa.

\section{Tabel 3.}

Presentase (P) Banyaknya Kesalahan Jawaban Tiap Indikator

\begin{tabular}{clccl}
\hline No & Indikator Prncapaian Kompetensi Siswa & P Benar & P Salah & $\begin{array}{c}\text { Kriteria } \\
\text { Kesalahan }\end{array}$ \\
\hline 1. & Menentukan median dari data genap & $26 \%$ & $74 \%$ & Sedang \\
2. & Menetukan nilai rata-rata suatu data & $20 \%$ & $80 \%$ & Sedang \\
3. & Menentukan median dari data ganjil & $79 \%$ & $21 \%$ & Sangat Rendah \\
4. & Menganalisis suatu data & $17 \%$ & $83 \%$ & Tinggi \\
5. & Menentukan modus suatu data & $52 \%$ & $48 \%$ & Sangat Rendah \\
\hline
\end{tabular}

Berdasarkan Tabel 3 terlihat bahwa tingkat kesalahan jawaban siswa pada indikator menentukan median dari data genap dan menentukan nilai rata-rata suatu data berada pada kriteria sedang. Kemudian pada indikator menentukan median dari data ganjil berada pada kriteria sangat rendah. Pada indikator menganalisis suatu data, kurang dari seperempatnya yaitu 17\% siswa mampu mencapai 
indikator tersebut dan sebesar $83 \%$ siswa masih belum mampu menganalisis suatu data. Berdasarkan hal itu, pada indikator menganalisis suatu data kesalahan siswa berada pada kategori tinggi. Hal ini dikarenakan oleh siswa belum mampu memahami dan menganalisis data yang disajikan dalam diagram batang. Lalu pada indikator menentukan nilai modus pada suatu data terdapat lebih dari setengahnya siswa yaitu sebesar 52\% yang mampu menentukan nilai modus dari suatu data dan $48 \%$ siswa masih mengalami kesalahan dalam menentukn nilai modus dari suatu data. Hal tersebut dikarenakan siswa kurang teliti dalam mengelompokkan data berdasarkan nilai yang sama.

Berikut ini merupakan pembahasan jawaban pada siswa yang mendapatkan skor tidak sempurna pada setiap pertanyaan pada pokok bahasan statistika.

\section{Analisis Soal No 1}

Analisis jawaban siswa yang memperoleh nilai skor 5 pada pertanyaan nomor 1 dengan indikator pencapaian kompetensi menentukan nilai median dari data genap.

Nilai ulangan harian matematika dari 14 orang siswa yang diambil secara acak adalah 7, 5, 8, 6, 7, $8,7,7,7,9,5,8,6$, dan 8 . Median dari data tersebut adalah...

Berdasarkan pertanyaan tersebut diperoleh berbagai jawaban siswa. Berikut ini dapat disajikan salah satu jawaban siswa yang memiliki skor 5 dari skor maksimum 10 .

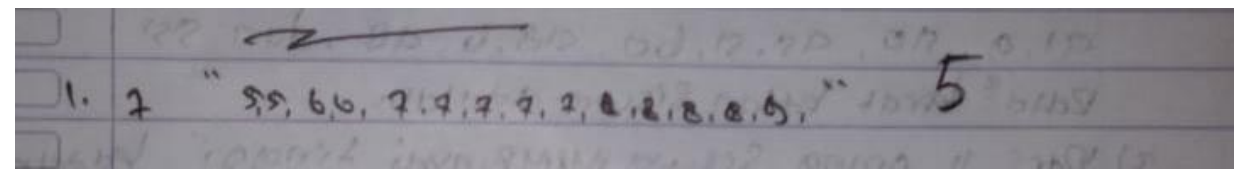

Gambar 1. Jawaban siswa pada no.1 yang memperoleh skor 5

Gambar 1 memperlihatkan bahwa jawaban siswa yang sudah berusaha menyelesaikan soal tersebut dengan benar. Siswa mencoba menentukan nilai median atau nilai tengah dari suatu data dengan cara mengurutkan nilai dari yang terkecil sampai yang terbesar. Namun pada jawaban siswa tersebut, kurang detail, karena tidak menyatakan dengan jelas nilai median yang didapat dari mana. Selain itu, siswa tidak menuliskan apa yang diketahui dan yang ditanyakan dalam soal, sehingga siswa kurang memahami data yang disajikan termasuk data tunggal atau data genap yang mengakibatkan keliru dalam mengerjakan soal tersebut. Sejalan dengan penelitian yang dilakukan oleh (Mahdayani, 2016) menyatakan bahwa siswa mengalami kesulitan pemahaman dalam konsep materi. Selain itu juga, berdasarkan penelitian yang dilakukan oleh (Seifi, Haghverdi, \& Azizmohamadi, 2014) menyatakan bahwa siswa kesulitan dalam memahami kalimat yang tertera dalam soal dan menerapkan strategi dalam menyelesaikan permasalahan tersebut.

\section{Analisis Soal No 2}

Analisis jawaban siswa yang memperoleh skor 15 dari skor maksimum 20 pada pertanyaan nomor 2 dengan indikator menentukan nilai rata-rata dari suatu data.

Berat badan sejumlah siswa (dalam satuan kilogram) adalah 36.8, 37.5, 41.9, 50, 45.5, 60, 58.6, 48 dan 55. Berdasarkan data tersebut, rata-rata berat badan siswa adalah... 


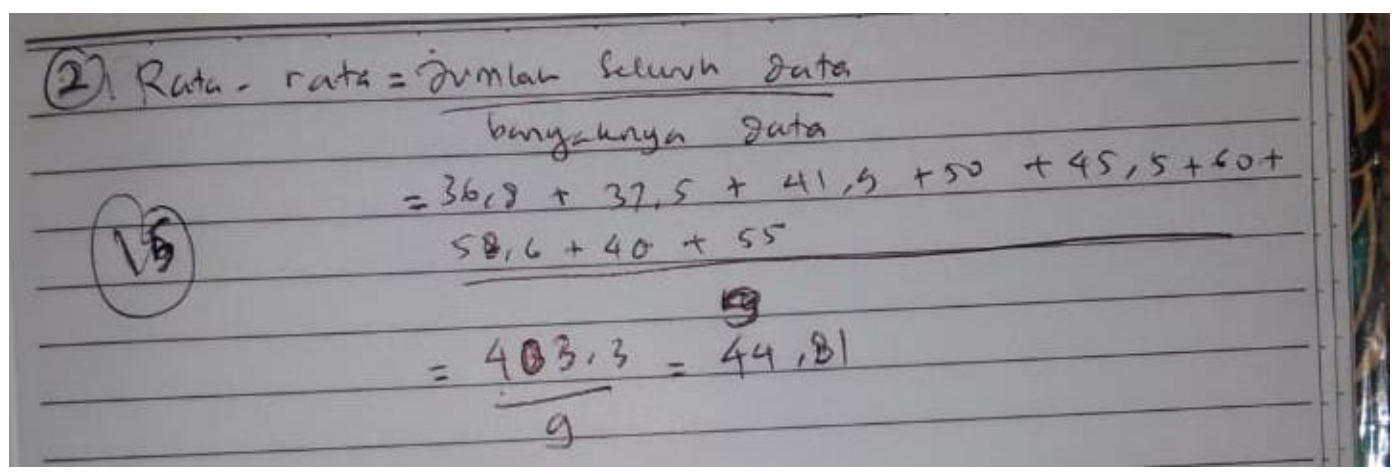

Gambar 2. Jawaban siswa pada no.2 yang memperoleh skor 5

Berdasarkan jawaban siswa pada gambar 2, siswa sudah mampu membuat pemodelan dengan benar, dengan menyatakan formula dari rata-rata, namun kesalahannya terletak pada hasil penjumlahan dari seluruh data yang disebabkan kurangnya ketelitian dalam mengoperasikannya. Sehingga, hasil yang diperoleh menjadi kurang tepat. Dalam penelitian yang dilakukan oleh (Mahdayani, 2016) berpendapat bahwa siswa mengalami kesulitan keterampilan proses dalam menyelesaikan persoalan yang disajikan sehingga hasil yang diharapkan kurang tepat. Hal ini sejalan dengan tahapan jenis kesulitan siswa menurut Newman (Mahdayani, 2016) pada tahap pengkodean (encoding level) yaitu tahap dimana siswa telah menemukan solusi atas permasalahan, akan tetapi salah menentukan jawaban akhir atau tidak menyajikan jawaban dengan tepat.

\section{Analisis Soal No 3}

Analisis jawaban siswa yang memperoleh skor 5 dari skor maksimum 10 pada pertanyaan nomor 3 dengan indikator menentukan nilai median dari data ganjil.

Dari 11 orang siswa mempunyai tinggi badan masing-masing 140, 150, 147, 148, 150, 165, 168, 170, 155, 157, dan 159. Mereka berdiri berjajar dari yang tertinggi hingga terendah dari kiri kekanannya. Berapa tinggi siswa yang ada di tengah?

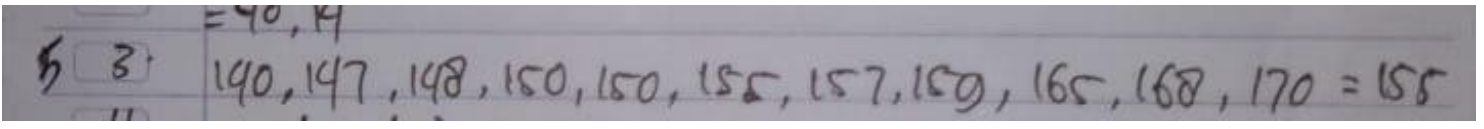

Gambar 3. Jawaban siswa pada no.3 yang memperoleh skor 5

Pada Gambar 3, memperlihatkan bahwa siswa tidak memahami pertanyaan dari soal tersebut. Hal itu ditunjukkan oleh data tinggi badan siswa di urutkan dari yang terendah hingga tertinggi, sedangkan dari permasalahan yang diketahui tinggi badan siswa diurutkan dari yang tertinggi hingga terendah. Selain itu, siswa belum mampu mengkomunikasikan cara yang digunakan dalam model matematika.

\section{Analisis Soal No 4}

Analisis jawaban siswa yang memperoleh skor 12 dari skor maksimum 30 pada pertanyaan nomor 4 dengan indikator menganalisis suatu data.

Grafik dibawah menunjukkan hasil panen padi di suatu wilayah. 


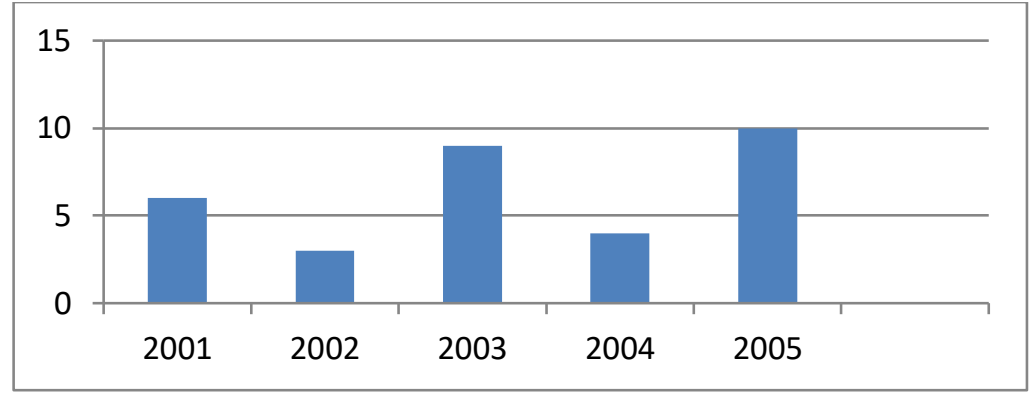

Grafik 1. Hasil panen padi di suatu wilayah

Berdasarkan grafik diatas, modus dan rata-rata hasil panen padi tersebut adalah...

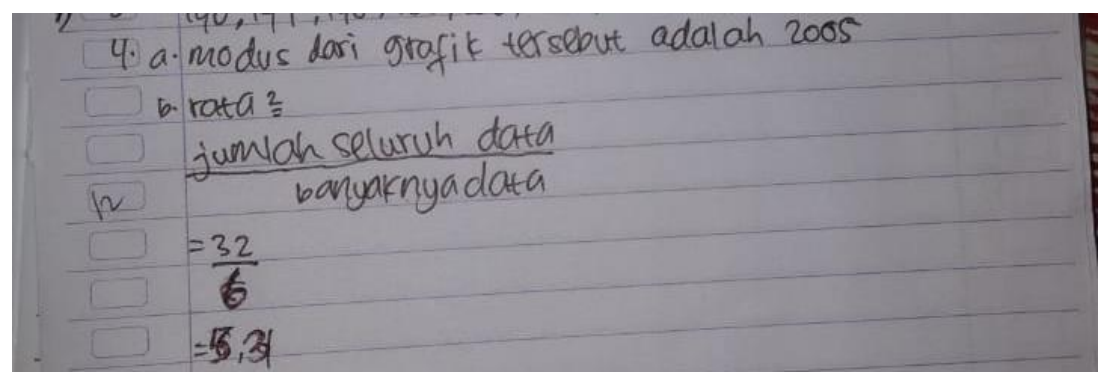

Gambar 4. Jawaban siswa pada no.4 yang memperoleh skor 12

Berdasarkan gambar 4, siswa sudah mampu memahami maksud dari soal tersebut ke dalam model matematika. Tetapi letak kesalahannya adalah jumlah dari seluruh data yang disajikan dan banyaknya data yang terdapat dalam grafik tidak sesuai, sehingga hasil yang diharapkan menjadi kurang tepat. Hal ini sejalan dengan pernyataan (Maryati, 2017), bahwa kesulitan siswa pada materi statistika salah satunya adalah melakukan manipulasi statistik, sehingga menjadi kendala dalam penarikan kesimpulan.

\section{Analisis Soal No 5}

Analisis jawaban siswa yang memperoleh skor 15 dari skor maksimum 30 pada pertanyaan nomor 5 dengan indikator menentukan nilai modus dari suatu data. Dari 30 nilai siswa sebagai berikut: 78 , 79, 40, 61, 48, 49, 65, 70, 81, 79, 68, 65, 72, 74, 40, 65, 61, 79, 81, 73, 79, 45, 80, 48, 90, 82, 78, 80, 89 dan 73. Mereka diminta membuat kelompok sesuai dengan nilai yang sama. Berapa nilai pada kelompok anggota paling banyak...

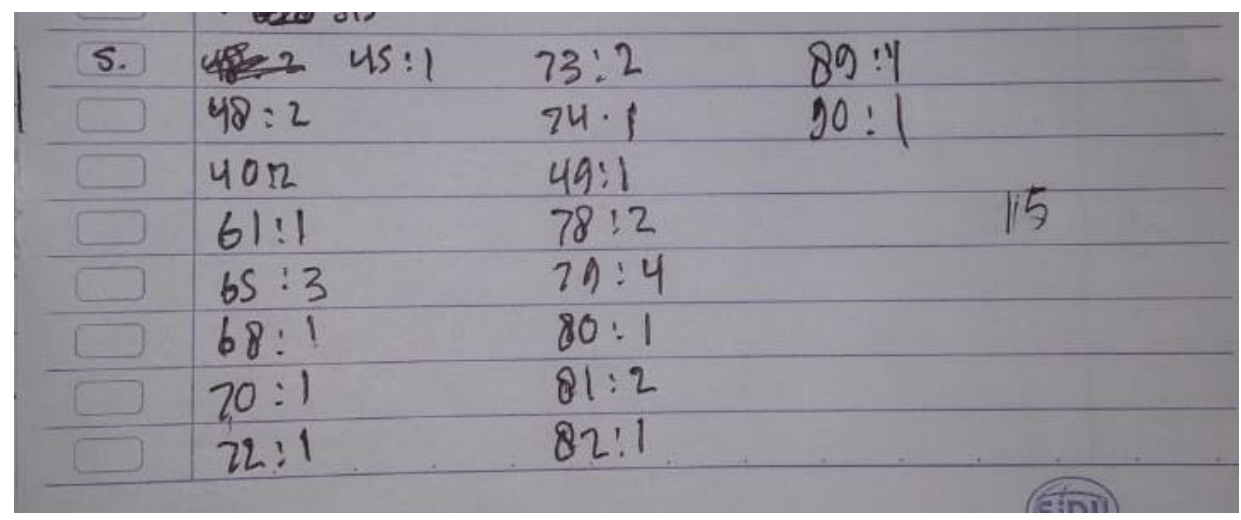

Gambar 5. Jawaban siswa pada no.5 yang memperoleh skor 15

Berdasarkan jawaban siswa pada gambar 5, memperlihatkan bahwa siswa mampu memahami soal 
tersebut dengan mengidentifikasi terlebih dahulu jumlah data yang memiliki nilai yang sama. Namun, setelah dikelompokkan siswa tidak menarik kesimpulan pada nilai berapa yang termasuk pada kelompok anggota paling banyak. Seperti yang dikatakan oleh (Maryati, 2017), bahwa salah satu kesulitan siswa pada materi statistika adalah menarik kesimpulan yang dipengaruhi oleh faktor kurangnya pemahaman siswa terhadap materi statistika.

\section{KESIMPULAN}

Berdasarkan hasil penelitian dan pembahasan, analisis kesulitan siswa dalam mengerjakan soal pada pokok bahasan statistika dapat disimpulkan bahwa kesalahan terbanyak yang dikerjakan oleh siswa berada pada indikator menentukan nilai rata-rata dari suatu data dengan presentase kesalahan $80 \%$ dan pada indikator menganalisis suatu data dengan presentase kesalahan $83 \%$ yang termasuk kategori tinggi. Faktor penyebabnya adalah siswa belum mampu memahami konsep dasar statistika, mengkomunikasikan permasalahan dengan cara memodelkan matematika, melakukan manipulasi statistik, dan menarik kesimpulan.

\section{DAFTAR PUSTAKA}

Aprilianti, Y., \& Zanthy, L. S. (2018). Analisis Kemampuan Penalaran Matematik Siswa SMP pada Materi Segiempat dan Segitiga. Journal On Education, 01(02), 524-532.

As'ari, A. R., Tohir, M., Valentino, E., Imron, Z., \& Taufiq, I. (2017). Buku Guru Matematika SMP/MTs Kelas VIII.

Chotimah,S; Ramdhani, F,. A.; Martin Bernard, M.; \& Akbar, P. (2015). Pengaruh Pendekatan Model-Eliciting Activities Terhadap Kemampuan Komunikasi Matematik Siswa SMP. Journal of Education, 1, 68-77. https://doi.org/10.22460/p2m.v2i1p40-45.162

Faelasofi, R. (2017). Identifikasi Kemampuan Berpikir Kreatif Matematika Pokok Bahasan Peluang. JURNAL E-DuMath, 3(2), 155-163. https://doi.org/10.26638/je.460.2064

Farhan, M. S., \& Zanthy, L. S. (2019). Analisis Kesulitan Matematika Siswa MA dalam Menyelesaikan Soal Menggunakan Taksonomi Bloom. 2(5), 307-314.

Kemendikbud. (2019). Laporan Hasil Ujian Nasional. Pusat Penilaian Pendidikan. Retrieved from https://hasilun.puspendik.kemdikbud.go.id

Mahdayani, R. (2016). Analisis Kesulitan Siswa dalam Pemecahan Masalah Matematika pada Materi Aritmetika, Aljabar, Statistika, dan Geometri. Jurnal Pendas Mahakam, 1(1).

Maryati, I. (2017). Analisis Kesulitan Dalam Materi Statistika Ditinjau Dari Kemampuan Penalaran Dan Komunikasi Statistis. Prisma, 6(2), 173-179. https://doi.org/10.35194/jp.v6i2.209

Nisa, S., \& Susanti, E. (2019). Kemampuan Penalaran Statistis Siswa pada Materi Penyajian Data Histogram melalui Pembelajaran PMRI. Jurnal Pendidikan Matematika, 13(1), 21-40.

Seifi, M., Haghverdi, M., \& Azizmohamadi, F. (2014). Recognition of Students ' Difficulties in Solving Mathematical Word Problems from the Viewpoint of Teachers Recognition of Students

' Difficulties in Solving Mathematical Word. Journal of Basic and Applied Scientific Research, 2(April). 